\title{
WILU 2008 Announcement and Second Call for Papers
}

Kelowna, BC, Canada

May 14 16, 2008

WILU is one of the preeminent conferences on instruction and information literacy. The 2008 Conference will be at the University of British Columbia Okanagan campus, and in keeping with the Okanagan ${ }^{1}$ s growing reputation for its wine and wineries, the conference theme is Information Literacy Uncorked: Innovate, Celebrate, Participate.

We hope to have presentations that focus on three themes we have identified for the conference: conceptual foundations/theory, practice, and innovation. One of our innovations this year is the Lightning Strike: a 10 minute session where you can present, in a more focused format, your concept or practice.

The deadline for proposals is December 14, 2007, and can be submitted via the website at http://www.library.ubc.ca/wilu2008/

For the submission form and further information about the conference, including suggested topics and presentation formats please go to: http://www.library.ubc.ca/wilu2008/

If you have any questions about the submission process or anything else related to WILU 2008, please contact me and I will do my best to assist you.

\section{Appel pour présentations WILU 2008}

Kelowna, Colombie-Britannique, Canada 14-16 mai 2008

La conférence WILU mise sur la litéracie de linformatique et de l'instruction. La conférence de 2008 se déroulera au campus de la University of British Columbia Okanagan. Le thème, Information iteracy Uncorked : Innovate, Celebrate, Participate, reflète la grande renommée vinicole de cette région du Canada. Les présentations doivent porter sur les thèmes suivants : bases fondamentales conceptuelles, théorie, pratique et innovation. Une de nos innovations $\mathrm{c}^{1} \mathrm{est}$ de présenter THE LIGHTENING STRIKE une session de 10 minutes qui porte sur un concept ou une pratique que vous voulez partager avec vos pairs. La date limite pour les propositions : le 14 décembre, 2007 Pour soumission par courriel, veuillez cliquer ici http://www.library.ubc.ca/wilu2008/

Pour de plus amples renseignements, veuillez vous dirigez au site suivant: http://www.library.ubc.ca/wilu2008/ 